\title{
ArcheoSciences
}

Revue d'archéométrie

$29 \mid 2005$

Varia

\section{Synchrotron et archéométrie}

Compte rendu de table ronde

synchrotron and archaeometry

Loïc Bertrand et Philippe Dillmann

\section{CpenEdition}

Journals

Édition électronique

URL : http://journals.openedition.org/archeosciences/709

DOI : $10.4000 /$ archeosciences.709

ISBN : 978-2-7535-1594-9

ISSN : 2104-3728

Éditeur

Presses universitaires de Rennes

\section{Édition imprimée}

Date de publication : 31 décembre 2005

Pagination : 169-171

ISSN : 1960-1360

Référence électronique

Loïc Bertrand et Philippe Dillmann, «Synchrotron et archéométrie », ArcheoSciences [En ligne], 29 |

2005, mis en ligne le 31 décembre 2005, consulté le 11 février 2021. URL : http://

journals.openedition.org/archeosciences/709; DOI : https://doi.org/10.4000/archeosciences.709

Ce document a été généré automatiquement le 11 février 2021.

Article L.111-1 du Code de la propriété intellectuelle. 


\title{
Synchrotron et archéométrie
}

\author{
Compte rendu de table ronde \\ Synchrotron and archaeometry
}

Loïc Bertrand et Philippe Dillmann

\section{Version française}

1 Le 21 avril 2005, à l'issue de la session consacrée aux potentialités du rayonnement synchrotron en archéométrie s'est tenue une table ronde dont nous proposons ici de résumer les principales interventions. Cet échange visait à recenser les principales attentes des chercheurs des sciences humaines dans le contexte du démarrage prochain (fin 2006) du nouveau synchrotron français, SOLEIL (Gif-sur-Yvette), et de la mise en place par le synchrotron d'une interface dédiée aux utilisateurs du patrimoine. La discussion fut chaleureuse et animée avec les interventions de 17 personnes sur environ 55 participants.

2 La table ronde débutait par une présentation de Philippe DILLMAN qui résuma les principales spécificités du synchrotron (temps d'acquisition courts, grand nombre de techniques) mais aussi les limitations actuelles à l'accès des équipes sciences humaines (élaboration des comités de programme). Pour l'étude des matériaux archéologiques, dont $\mathrm{PhD}^{1}$ soulignait l'hétérogénéité, les caractéristiques du rayonnement synchrotron peuvent être particulièrement intéressantes (microfaisceau, imagerie, sélectivité chimique). Par contraste avec les demandes émanant des laboratoires plus orientés "patrimoine ", PhD insistait en archéométrie sur l'utilisation possible de méthodes invasives. Enfin, en posant la question «le rayonnement synchrotron est-il archéomatériaux-compatible ", $\mathrm{PhD}$ s'interrogeait sur les procédures d'accès, les approches systématiques dans le cadre d'analyses complexes, l'implication potentielle d'organismes (CNRS SHS, Ministère de la Culture) et la nécessité de former des chercheurs aux interfaces.

3 Les principaux points évoqués lors de la table ronde, sont ordonnés selon les trois thématiques centrales abordées. 


\section{Axes scientifiques et données techniques}

Plusieurs intervenants ont évoqué des axes scientifiques pouvant bénéficier de l'apport du rayonnement synchrotron : archéométallurgie des demi-produits ferreux corroyés $(\mathrm{PhF})$, fibres cellulosiques (VR), corrosion des cuivreux (JMW), conservation / restauration $(\mathrm{NH})$.

5 Les potentialités signalées comme les plus intéressantes sont l'imagerie micro-faisceau à la résolution de quelques micromètres $(\mathrm{PhD}, \mathrm{PhF}, \mathrm{VR}, \mathrm{JMW})$, les analyses en séries ( $\mathrm{PhF}, \mathrm{MFG}, \mathrm{PhD})$, la spéciation chimique par absorption des rayons $\mathrm{X}$ ( $\mathrm{PhD}, \mathrm{JMW})$. MC et LB ont précisé que la résolution dépendait de la longueur d'onde: typiquement 3 à $5 \mu \mathrm{m}$ pour l'infrarouge entre 700 et $4000 \mathrm{~cm}^{-1}$, bien moindre pour les RX avec une limite technologique à ce jour autour de cent nanomètres pour les rayons $\mathrm{X}$ de moyenne énergie.

6 Les problèmes de détérioration sous faisceau ont été soulevés, notamment pour les matériaux biologiques et les phases isolantes (JR, PhC). ED et JD ont souligné que ces risques étaient réels, mais connus des responsables de lignes qui y sont confrontés quotidiennement. La vitesse d'altération dépend fortement des matériaux considérés : généralement négligeables pour les métaux, ils peuvent provoquer la coloration locale de verres, voire détruire en quelques dizaines de secondes un matériau organique. ED souligne que la dégradation est limitée à la zone d'analyse, typiquement 1 micromètre carré en mode focalisé. En outre, sur les installations récentes, un temps d'acquisition de quelques secondes est généralement suffisant (diffraction des rayons $\mathrm{X}$ ), ce qui nous place bien en deçà de l'apparition des dégâts d'irradiation (JD).

\section{Organisation}

7 SOLEIL met actuellement en place une interface dédiée à l'archéologie et au patrimoine culturel. Celle-ci vise à permettre aux chercheurs de ces communautés d'y étudier plus facilement leurs échantillons, ainsi qu'à apporter support et expertise en contact direct avec les lignes de SOLEIL concernées (LB). ED souligne que d'autres synchrotrons réfléchissent à de telles interfaces (Italie, Grande-Bretagne, Allemagne, États-Unis), que le nombre de publications sur ces thématiques augmente constamment et qu'il est maintenant temps de se fédérer au niveau européen. JD indique également qu'un projet intégré au sein d'un synchrotron est la « clef du succès ».

Afin que les résultats obtenus soient crédibles aux yeux de la communauté, plusieurs intervenants ( $\mathrm{PhD}, \mathrm{PhF}, \mathrm{MFG}$ ) soulignent l'importance d'une approche statistique sur synchrotron. PhF précise que son équipe est prête à "passer à cette étape ", vue l'importance que cette approche revêt pour l'étude des chaînes opératoires. Pour l'analyse des métaux précieux, MFG insiste également sur ce besoin de statistiques, et sur le temps de traitement des données correspondant. Il s'agit d'une approche totalement inhabituelle sur synchrotron "sauf peut-être en biologie» $(\mathrm{PhD})$. Une réflexion autour de la prise en compte de ce besoin est amorcée à SOLEIL, dans le cadre du projet archéologie \& patrimoine mais également pour d'autres communautés scientifiques intéressées (LB).

9 IR et SL soulignent la nécessaire implication des responsables de ligne dans les projets, vu la diversité et la complexité des méthodes expérimentales. En outre, les méthodes 
peuvent (et doivent) au préalable avoir été testées en laboratoire (SL, MA). LB indique que SOLEIL souhaite mettre en place des partenariats avec des laboratoires disposant d'équipements de taille intermédiaire, afin d'être capable « de rediriger des utilisateurs vers d'autres installations" s'ils n'ont pas réellement besoin du rayonnement synchrotron. Un des buts de l'interface est de fournir une aide directe aux utilisateurs, pour la préparation des échantillons comme pour l'analyse des données, en contact direct avec le personnel des lignes d'analyse.

10 Dans ce domaine, la formation des chercheurs est un point clé (VR, NH). NH précise que s'il est nécessaire que " les archéomètres se forment au synchrotron ", il est également nécessaire que « les gens du synchrotron se forment à l'archéométrie ». LB souligne que la participation de nombreux chercheurs de SOLEIL à ce colloque va dans ce sens, et rappelle que SOLEIL a organisé fin 2004 la première formation au niveau mondial sur l'utilisation des méthodes synchrotron pour l'étude des matériaux anciens. MA précise qu'il s'agit également d'une préoccupation du GdR Matériaux du patrimoine \& synchrotron SOLEIL (échange avec des formations, réunions, invitation de jeunes scientifiques sur des expériences programmées, forum internet).

\section{Interdisciplinarité, soutien institutionnel et évaluation}

11 AP et ED soulignent que l'interdisciplinarité ne doit pas se faire aux dépens des compétences de chacun et que la collaboration est la bonne solution. Alors que $\mathrm{NH}$ souhaite la création de poste « aux interfaces », MFG précise que l'« archéomètre » doit précisément jouer ce rôle d'interface.

12 En début de table ronde PhF avait évoqué un investissement du département SHS vis-àvis de l'interface de SOLEIL. MFG suggère également un tel engagement à l'image de celui des sciences chimiques du CNRS.

13 Enfin, NH et NT soulèvent le problème de l'évaluation des projets d'archéométrie par les futurs comités de programme de SOLEIL, notamment pour les projets «terre à terre » absolument nécessaires à la conservation-restauration $(\mathrm{NH}) . \mathrm{PhD}$ indique que recherche en amont et applications ne doivent pas être dissociées en archéométrie. PhF souligne l'importance des comités de programme, ne serait-ce pour ne pas « prêter à la critique ». Les sciences humaines, l'archéologie et la conservation-restauration devraient être mieux représentées dans les comités de programme (NT, PhD, VR). SL précise que le Ministère de la Culture s'est posé ces questions pour la mise en place de son Programme national de recherche sur la connaissance et la conservation des matériaux du patrimoine culturel (PNRC). Ce point fait également l'objet d'intenses réflexions pour l'interface de SOLEIL, il s'agirait alors d'une approche totalement novatrice au sein d'une installation synchrotron (LB).

\section{English version}

On the 21th April 2005, following the session dedicated to the potentialities of synchrotron radiation for archaeometry, was held a round table that we suggest to summarise here. These exchanges aimed at identifying the main expectations from Humanities researchers in the context of the start of operations (end of 2006) of the new French synchrotron source SOLEIL (Gif-sur-Yvette) and of the setting-up by SOLEIL 
of a liaison office dedicated to heritage users. The discussion was warm and vivid with interventions from 17 persons among around 55 participants.

The round table started by a presentation from Philippe DILLMANN who summarized the main specificities of synchrotron (short acquisition times, large number of techniques) but also the main limitations to the access of Humanities teams (composition of the review committees). Synchrotron radiation characteristics (microbeam, imaging, chemical selectivity) can be particularly interesting for the study of archaeological materials of which $\mathrm{PhD}^{2}$ underlined the heterogeneity. In contrast to the demand issued by "Heritagc"-oricnted laboratories, $\mathrm{PhD}$ insisted on the possibility to use invasive techniques for archaeometry purposes. Then, by asking "is synchrotron radiation archaeomaterial-compatible", $\mathrm{PhD}$ questioned the access procedure, the possibility of systematic approaches in the framework of complex analyses, the potential implication of French research bodies (CNRS Humanities and Social Sciences Department, French Ministry of Culture) and the requirements to train researchers at the interfaces.

The main points of the discussion have been re-organized following the three central themes evoked at the round table.

\section{Scientific axes and technical requirements}

17 Several participants evoked the scientific axes that could most benefit from the contribution of synchrotron radiation: archaeometallurgy of welded iron half-products $(\mathrm{PhF})$, cellulose fibres (VR), cuprous compound corrosion (JMW), conservation and restoration (NH).

The potentialities underlined as the most interesting are microbeam imaging at a few micrometer resolution (PhD, PhF, VR, JMW), series analyses (PhF, MFG, PhD), chemical speciation using X-ray absorption (PhD, JMW). MC and LB indicated that the resolution depends on the wavelength: ranging typically from 3 to $5 \mu \mathrm{m}$ for infrared microscopy between 700 et $4000 \mathrm{~cm}^{-1}$, far less for X-rays with a technological limit today at around $100 \mathrm{~nm}$ for medium X-rays.

Radiation damages were evoked primarily for biological materials and isolating phases (JR, PhC). ED and JD underlined that these risks were real yet well-known to beamline responsibles who are daily coping with them. The damage rate depends strongly on the material considered: usually negligible for metals, they can induce the local coloration of glass, or even destroy an organic sample in a few dozens of seconds. However, ED underlines that the degradation is limited to the beam footprint, i.e. typically a square micrometer in focussed mode. Moreover, for recent facilities, an acquisition time of a few seconds is usually sufficient (X-ray diffraction) far less than the duration leading to radiation damages (JD).

\section{Organisational aspects}

SOLEIL is setting up a liaison office dedicated to archaeology and cultural heritage. Its aim is to bring support and expertise to the scientists coming from these communities and to help them for the study of their samples in direct contact with the relevant beamlines at SOLEIL (LB). ED underlines that other synchrotron facilities around the world try to set up such interfaces for example in the UK, in Germany and in the United 
States. The number of publications dealing with these themes increases steadily at an international level and it is now time to federate the community at a European level. JD indicates that an integrated project attached to a synchrotron facility is the "key to success".

In order to ensure the best quality of results for the community, several participants (PhD, PhF, PPG) underline the need of a statistical approach for archaeological artefacts, and that it should be possible at a synchrotron source. PhF adds that his team is ready to carry up this sort of work and underlines the significance of such an approach to understand ancient metallurgy operating chains. MFG also underlines the need of a statistical approach to study precious metals, but also the necessity to take into account the amount of time required to process the huge quantity of data generated. This approach is quite unusual at synchrotron facilities and is only encountered for biology (PhD). SOLEIL is currently looking for a way to address this need in the framework of the "archacology and heritage" project. Other scientific communities are also interested by these new developments (LB).

IR and SL underline the necessary implication of beamline scientists in the projects due to the complexity and diversity of experimental methods available at synchrotron facilities. Moreover, experiments should have been tested using laboratory equipment prior to any synchrotron access (SL, MA). LB indicates that SOLEIL wishes to establish a tight partnership with partner laboratories possessing in-house experimental set-ups at their disposal that could be used when synchrotron radiation is not strictly required. One of the aim of the liaison office at SOLEIL is to provide direct support to users from sample preparation to data processing in direct contact with beamline scientists.

In the field, the training of scientists is a key factor (VR, NH). NH underlines that if it is necessary that "the scientists in archaeometry learn more about synchrotron", it is also necessary that "scientists at synchrotrons learn more about heritage and archaeological issues". LB indicates that the participation of numerous scientists of SOLEIL to this congress is a first step and that SOLEIL organised at the end of 2004 the first ever international school on the use of synchrotron techniques to study ancient materials. MA indicates that it is also an aim of the GdR "Matériaux du Patrimoine et Synchrotron SOLEIL" [Heritage materials and SOLEIL synchrotron]: exchanges of scientists between laboratories, invitation of young scientist to specific experiments at synchrotron facilities, etc.

\section{Interdisciplinarity, institutional support and evaluation}

AP and ED underline that interdisciplinarity should not put at risk each partner competencies and that collaborating is the best solution. $\mathrm{NH}$ wishes the opening of positions "at the interfaces", whereas MFG underlines that the "archaeometer" should precisely play this role.

At the beginning of the round table PhF had evoked a possible involvement of the CNRS Humanities and Social Sciences Department in the SOLEIL liaison office. MFG backs such an involvement that could be comparable to that of the CNRS Chemistry Department in SOLEIL.

26 Finally, NH and NT raise the issue of the evaluation of archaeometry projects by the future SOLEIL review committees, in particular for "workaday" projects absolutely necessary to conservation-restoration purposes $(\mathrm{NH})$. $\mathrm{PhD}$ indicates that basic research 
and applications should not be dissociated in archaeometry. PhF stresses the importance of review committees as a way "not to invite to criticism". Humanities, Archaeology and Conservation-restoration should be better represented in review committees (NT, PhD, VR). SSL specifics that the French Ministry of Culture faced these issues for the setting-up of its Programme national de recherche sur la connaissance et la conservation des matériaux du patrimoine culturel [National research program for the understanding and conservation of cultural heritage materials]. This point is also the subject of intense reflection at the SOLEIL liaison office, it would then be a completely novel approach at a synchrotron facility (LB).

\section{NOTES}

1. Dans la suite du texte, les intervenants sont identifiés par leurs initiales :

Michel ANNE (MA) LdC, Grenoble

Loïc BERTRAND (LB) interface archéologie et patrimoine, Synchrotron SOLEIL

Philippe COLOMBAN (PhC) LADIR, Thiais

Marine COTTE (MC) ESRF, Grenoble

Philippe DILLMANN (PhD) laboratoire Pierre SÜE, Saclay

Eric DOORYHEE (ED) LdC, Grenoble

Jean DOUCET (JD) LPS, Orsay

Philippe ELUZIN (PhF) LMC, Belfort

Maria Filomena GUERRA (MFG) C2RMF, Paris

Nathalie HUET (NH) laboratoire Arc'Antique, Nantes

Stéphane LEQUIEN (SL) laboratoire Pierre SÜE, Saclay

Alain PLOQUIN (AP) CRPG, Vandoeuvre-lès-Nancy

Ina REICHE (IR) C2RMF, Paris

Josep ROQUE (JR) Universitat de Barcelona, Barcelone, Espagne

Véronique ROUCHON (VR) CRCDG, Paris

Nicolas THOMAS (NT) 1NRAP, Paris

Jean-Marie WELTER (JMW) SF2M, Sérifontaine

2. In the following text, participants are designated by their initials:

Michel ANNE (MA) LdC, Grenoble

Loïc BERTRAND (LB) archaeology and heritage liaison office, SOLEIL synchrotron

Philippe COLOMBAN (PhC) LADIR, Thiais

Marine COTTE (MC) ESRF, Grenoble

Philippe DILLMANN (PhD) Pierre SUE laboratory, Saclay

Eric DOORYHEE (ED) LdC, Grenoble

Jean DOUCET (JD) LPS, Orsay

Philippe FLUZIN (PhF) LMC, Belfort

Maria Philomena GUERRA (MFG) C2RMF, Paris

Nathalie HUET (NH) Arc'Antique laboratory, Nantes

Stéphane LEQUIEN (SL) Pierre SUE laboratory, Saclay

Alain PLOQUIN (AP) CRPG, Vandoeuvre-les-Nancy

Ina REICHE (IR) C2RMF, Paris 
Josep ROQUE (JR) Universitat de Barcelona, Barcelona, Spain Véronique ROUCHON (VR) CRCDG, Paris

Nicolas THOMAS (NT) INRAP

Jean-Marie WELTER (JMW) SF2M, Sérifontaine 